$\frac{120 / 27-82}{10,28}=$

$$
\text { \$1 } I-6090
$$$$
\text { NASA TM-82900 }
$$

\title{
On the Road Performance Tests of Electric Test Vehicle for Correlation with Road Load Simulator
}

Miles O. Dustin and Ralph J. Slavik

National Aeronautics and Space Administration Lewis Research Center

August 1982

Prepared for

U.S. DEPARTMENT OF ENERGY

Conservation and Renewable Energy

Office of Vehicle and Engine R\&D 


\section{DISCLAIMER}

This report was prepared as an account of work sponsored by an agency of the United States Government. Neither the United States Government nor any agency Thereof, nor any of their employees, makes any warranty, express or implied, or assumes any legal liability or responsibility for the accuracy, completeness, or usefulness of any information, apparatus, product, or process disclosed, or represents that its use would not infringe privately owned rights. Reference herein to any specific commercial product, process, or service by trade name, trademark, manufacturer, or otherwise does not necessarily constitute or imply its endorsement, recommendation, or favoring by the United States Government or any agency thereof. The views and opinions of authors expressed herein do not necessarily state or reflect those of the United States Government or any agency thereof. 


\section{DISCLAIMER}

Portions of this document may be illegible in electronic image products. Images are produced from the best available original document. 


\section{NOTICE}

This report was prepared to document work sponsored by the United States Government. Neither the United States nor its agent, the United States Department of Energy, nor any Federal employees, nor any of their contractors, subcontractors or their employees, makes any warranty, express or implied, or assumes any legal liability or responsibility for the aoouracy, completeness, or ucofulnogs of any information, apparatus, product or process disclosed, or represents that its use would not infringe privately owned rights 


\section{On-the-Road Performance Tests of Electric Test Vehicle for Correlation with Road Load Simulator}

Miles O. Dustin and Ralph J. Slavik

National Aeronautics and Space Administration Lewis Research Center

Cleveland, Ohio 44135
This report was prepared as an account af work sponsored by an opency of the United States Government. Neither the United States Government nor any agency thereof. nor any of their employees. makes any

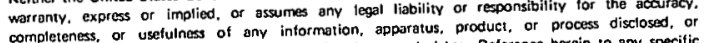
copresents stat its use would not infringe privately owned rights. Reterence herein to any specific

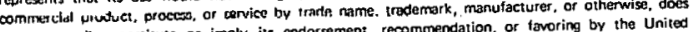
not necessomy constitute or imply its endorsement, recommendation, ears expressed herein do not States Government or any agency thereof. The views and opinions al aulhors bxprest.

\section{rory}

PORTIONS OF THIS REPORT ARE ILLEGIBLE. It has been reproduced from the best availablo eopr to permit the broadest possible availability:

August 1982

Work performed for

U.S. DEPARTMENT OF ENERGY

Conservation and Renewable Energy

Office of Vehicle and Engine R\&D

Washington, D.C. 20545

Under Interagency Agreement DE-A101-77CS51044 
ON THE ROAD PERFORMANCE TESTS OF ELECTRIC TEST VEHICLE FOR

CORRELATION WITH ROAD LOAD SIMULATOR

Miles 0. Dustin and Ralph J. Slavik

National Aeronautics and Space Administration

Lewis Research Center

Cleveland, Ohio 44135

\section{SUMMARY}

To test and evaluate electric vehicle propulsion systems under DOE'S Electric and Hybrid Vehicle Program, the Road Load Simulator (RLS) is being used at NASA's Lewis Research Center. This special purpose dynamometer provides tire resistance and aerodynamic loads which duplicate on the road conditions. To obtain realistic road load data and to correlate track tests with RLS tests, performance tests have been conducted on a propulsion system test vehicle at the Transportation Research Center of Ohio. The electric propulsion system test vehicle was built from the ground up as an electric vehicle. The series wound motor operates at 84 volts and is rated at 14.7 kilowatts $(20 \mathrm{hp})$. It operates from a chopper-type controller.

Vehicle performance tests included range at constant speeds and over SAE J227a driving cycles, maximum acceleration, and maximum gradability tests. Road power and energy consumption were determined from coast-down tests. Tire rolling resistance was determined by towing the vehicle with another vehicle using a load cell to measure towing force.

The range of the vehicle at a constant speed of 40 kilometers per hour (25 $\mathrm{mph}$ ) was $100 \mathrm{kilometers} \mathrm{(62} \mathrm{miles),} \mathrm{at} 56 \mathrm{kilometers} \mathrm{per} \mathrm{hour} \mathrm{(} 35 \mathrm{mph}$ ) it was $84 \mathrm{kilometers}(52 \mathrm{miles})$, and at $69 \mathrm{kilometers} \mathrm{per} \mathrm{hour} \mathrm{(} 43 \mathrm{mph}$ ) it was 58 kilometer ( 36 miles). Over the SAE J227a Schedule B driving cycle the range was 48 kilometers ( 30 miles), and over the Schedule C driving cycle it was 37 kilometers (23 miles).

\section{INTRODUCTION}

The NASA Lewis Research Center is responsible for testing and evaluating electric and hybrid vehicle propulsion systems for the Department of Energy (DOE). As a part of this program, a special purpose dynamometer, the Road Load Simulator (RLS), has been installed at Lewis for testing electric vehicle propulsion systems. The tests conducted on an electric test vehicle at the Transportation Research Center of Ohio will be compared with tests conducted on the same vehicle in the Road Load Simulator. Thesê comparisons of battery and motor currents and voltages will be at identical values of road load and will allow improved correlation between track and laboratory tests. Additional performance tests were conducted and are described in this report.

\section{Vehicle Description}

General. - The NASA Lewis Research Center electric propulsion system test vehicle (fig. 1) was built to evaluate electric vehicle propulsion systems on the road. The front wheel drive vehicle was built from the ground up by the Electric Vehicle Engineering Co. (EVE) of Boston, Massachusetts, using chassis 
parts from existing vehicles where possible. The frame, built by EVE, incorporates a central battery tunnel as shown in figure 2. The front and rear suspension system, springs, wheels, and brake system were made by Saab. The fiberglass body was made by Fiberfab Inc. of Fremont, California.

Motor. - The motor (fig. 3) was manufactured by Northwestern Electric Company of Chicago, Illinois. It is a four-pole machine with a series field winding. Rating data and dimensions are given in table $I$. The motor is force ventilated from an external fan with 0.118 cubic meter per second $(250 \mathrm{ft} 3 / \mathrm{min})$ of air required. The continuous duty output power rating is 14.7 kilowatts $(20 \mathrm{hp})$. The motor was thoroughly tested previously by Lewis Research Center to study the effects of chopper control on dc motor performance. The results of this study are reported in reference 1 .

Controller. - The controller, a Pulsomatic Mark 10 furnished by Cableform Incorporated of Troy, Virginia, provides infinitely variable control of a dc series wound motor. This is done by interrupting the battery voltage to the motor hy a silicon controlled rectifier (SCR) switch in a repetitive manner such that the motor receives a series of rapid voltage pulses. Since the pulse width is proportional to the throttle position, the average motor vollage is linear with throttle position. At low throttle positions the controller furnishes a 1-millisecond-wide ON pulse. As the throttle demand increases, the time between pulses (or OFF period) becomes shorter and the ON pulse becomes longer until both the ON pulse and the OFF period equal 2 milliseconds each, the frequency being 250 cycles. Further throttle increases result in longer ON pulses, and the OFF periods become shorter until the OFF periods are reduced to 1 millisecond. Further throttle increases cause the off period to become zero and the motor is directly connected to the battery. The controller consists of three separate units described as follows:

(1) Speed control unit. This box contains the control electronics of the controller and determines the output pulse frequency and duration. An input shaft protruding from this unit is attached to the throttle linkage.

(2) Power unit. This unit houses the SCR power switch that controls the power applied to the motor. Aluminum extrusions form heat sinks for the SCR's.

(3) Motor unit. The motor unit contains all of the components associated with power conditioning for the motor such as the forward and reverse contactors and free wheeling diode. The heavy aluminum case provides diode heat sinking.

A simplified diagram of the controller is shown in figure 4.

Differential. - Thé motor is coupled directly to the differential as there is no transmission in the vehicle. The differential ratio is 5.17. An alternate differential supplied with the vehicle has a ratio of 7.83 . 


\section{INSTRUMENTATION}

The vehicle was instrumented to accomplish the following objectives:

(1) To determine tire and aerodynamic characteristics for programming the RLS.

(2) To obtain performance data on the vehicle that could be compared with data from similar tests on the RLS.

Thermocouple measurements of tire-contained air temperature and vehicle speed were made while performing coast-down and towing tests to accomplish the first objective. Motor and battery current, motor and battery voltage, and vehicle speed were recorded during vehicle performance tests. All measurements were recorded simultaneously on three Honeywe 11195 Electronik twochannel strip-chart recorders. A schematic of the vehicle instrumentation is shown in figure 5. Current was measured with coaxial shunts. To measure ampere-hours from the battery, a Curtis Model SHR-C3 current integrator was used. Vehicle speed was measured by a LABECO NC-7 fifth wheel. Accuracy of the fifth wheel was verified with a Kustom Electronics Model HR8 radar gun. The accuracy of the calibrated fifth wheel was estimated to be \pm 1.6 kilometers per second $( \pm 1.0 \mathrm{mph})$.

\section{TEST PROCEDURES}

The tests described in this report were performed at the 12-kilometer (7.5-mile) continuous loop test track at the Transportation Research Center of Ohio located near East Liberty, Ohio. A complete description of the track is given in appendix $A$. Before vehicle tests were started, the wheel alignment was checked and the brakes were inspected for excess drag. Instrumentation was then installed. The first runs were shakedown tests to familiarize the driver with the operating characteristics of the vehicle, to check the instrumentation, and to determine the vehicle maximum speed. Additional details of preparing the vehicle for testing and procedure used during the tests are given in appendix $B$.

Initial shakedown tests were run with the 7.83 ratio differential. The maximum speed attainable for wide open throttle runs was 53 kilometers per hour ( $33 \mathrm{mph}$ ) so the differential was removed and the 5.17 ratio differential was installed. The maximum wide open throttle speed was now 69 kilometers per hour (43 mph). Subsequent tests were conducted with the 5.17 ratio differential.

\section{Range Tests at Constant Speed}

The vehicle speed for the highest constant-speed range tests was determined during checkout tests of the vehicle. This speed was $69 \mathrm{kilometers} \mathrm{per}$ hour (43 $\mathrm{mph}$ ).

Range tests were run at constant speeds of 40, 56, and $69 \mathrm{kilometers} \mathrm{per}$ hour $(25,35$, and $43 \mathrm{mph})$. The speed was held constant within \pm 1.6 kilometers per hour (1 mph), and the test was terminated when the vehicle could no longer maintain 95 percent of the test speed. 
Schedules $B$ and $C$ for stop-and-go driving cycle profiles are shown in figure 6. A complete description of cycle tests is given in appendix $E$ of reference 2. A special instrument, called a cycle timer, was developed at the Lewis Research Center to assist in running these tests accurately. Details of the cycle timer are given in appendix $B$. The cycle tests were terminated when the cruise speed could not be attained in the time required under maximum acceleration.

\section{Acceleration and Coast-Down Tests}

The maximum acceleration of the vehicle was measured on a level road with the battery 10 and 80 percent discharged. Four runs were made at each of the battery states of charge in both directions on the same section of the test track in order to average out track abnormalities. Depth of discharge was determined from the number of ampere-hours removed from the batteries.

Coast-down tests were run in both directions on the same section of straight track. The results of the tests were used to determine road energy cunsurnption and road power requirements.

\section{Tire Rolling Resistance Tests}

Rolling resistance tests were conducted on the Trelleborg 165/SR13 radial tires. The rolling reșistance data will he used to program the RLS when correlating the vehicle from the track tests with results of similar tests on the Road Load Simulator.

The tests were conducted by towing the vehicle with another vehicle approx-

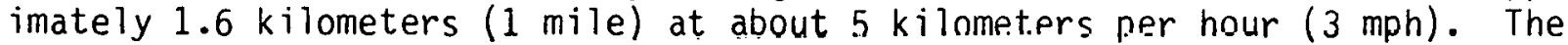
torce required to tow the vehicle, one front tire temperature, and the opposite tire pressure were continuously measured and recorded. The force measurement was made by attaching a load cell to the front bumper nf the test vehicle. The vehicle weight was distributed equally frunt and rear before the tests were started. Details on the test procedure are given in reference 3 .

\section{TEST RESULTS AND DISCUSSION}

\section{Rangc}

The results of all the range tests are summarized in table II. In the table are the test date, the type of tests, the weather conditions, the range test results, and the energy required to recharge the battery. SAE driving cycle range tests included both the $B$ and the $C$ driving cycle schedules. The $D$ cycle was not included because the vehicle can neither meet the acceleration requirements nor the required top speed to complete the cycle.

\section{Maximum Acceleration}

The maximum acceleration of the vehicle was determined with the batteries 10 and 80 percent discharged. The vehicle speed as a function of time is shown in figure 7 and table III. The first acceleration test was conducted with the battery partially discharged because it was performed after another 
test. This was necessary in order to accomplish the entire test program within the available time. Experience has shown that with Exide EV-106 batteries very. little degradation of acceleration performance occurs before the battery is 40 percent discharged. To obtain vehicle acceleration as a function of vehicle speed, the vehicle velocity as a function of time was fitted with a best fit curve as determined by the method of least squares. This curve was then differentiated to obtain the acceleration. Acceleration is shown as a function of vehicle speed in figure 8 and table III.

\section{Gradability}

The maximum specific grade, in percent, that a vehicle can climb at vehicle speed $V$ was determined from maximum acceleration tests by using either $G=100 \tan \left(\sin ^{-1} 0.0285 \mathrm{a}_{n}\right)$ for $V$ in $\mathrm{km} / \mathrm{hr}$ (SI units)

or

$G=100 \tan \left(\sin ^{-1} 0.0455 a_{n}\right)$ for $V$ in $m p h$ (U.S. customary units)

where $a_{n}$ is acceleration in kilometers per hour per second (mph/sec.). The maximuum grades the vehicle can negotiate as a function of speed are shown in figure 9 and table III.

\section{Road Energy}

Road energy is a measure of the energy consumed per unit of distance in overcoming the vehicles aerodynamic and rolling resistance loads plus the energy consumed in the drive train including the motor. Road energy was determined from coast-down tests, when the differential was being driven by the wheels, and thus may be different than the energy consumed when the differential is being driven by the motor.

The road energy consumption $E_{n}$ was calculated:

$$
E_{n}=2.78 \times 10^{-4} \mathrm{w} \frac{\mathrm{dv}}{\mathrm{dt}}, \frac{\mathrm{MJ}}{\mathrm{km}} \text { (SI units) }
$$

or

$E_{n}=9.07 \times 10^{-5} W \frac{d v}{d t}, \frac{k W-h r}{\text { mile }}$ (U.S. customary units)

where

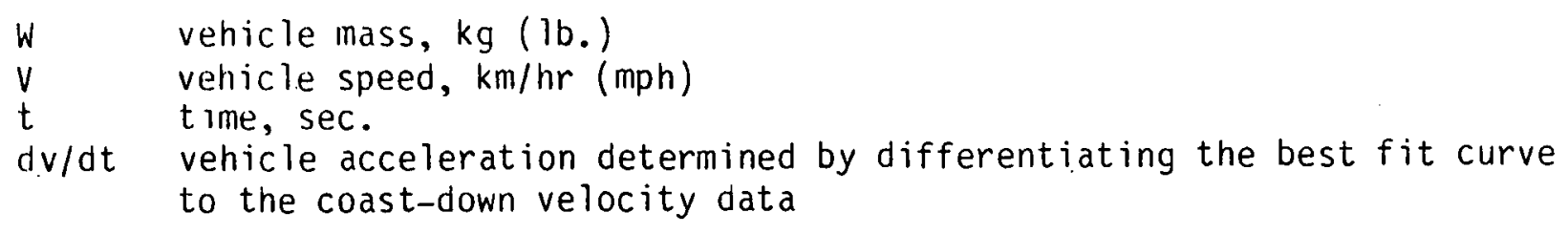

The results of the road energy calculations are shown in figure 10 and table IV. 
Road power is the power required to overcome the vehicle aerodynamics and tire rolling resistance plus the power losses in the power train. The power $P_{n}$ required to propel the vehicle at a function of velocity was also determined from the coast-down tests:

$P_{n}=3.86 \times 10^{-5} W V \frac{d v}{d t} k W$ (SI units)

or

$P_{n}=6.08 \times 10^{-5} \mathrm{~W} V \frac{d v}{d t}, h p$ (U.S. customary units)

The results of the power calculations are shown in figure 11 and table IV. Indicated tnergy Consumption

The vehicle indicated energy consumption is defined as the energy required to recharge the battery after a test divided by the vehicle range achieved during the test, where the energy is the input to the battery charger.

The energy input to the battery charger was measured with a residential kilowatt-hour meter after each range test. Some overcharge of the batteries was usually required to assure that all battery cells were fully charged. Because of overcharging the reported energy usage may be higher than would be experienced with normal vehicle field operation. Energy consumption as a function of vehicle speed is presented in figure 12 and table II for the constantspeed tests. Varying amounts of overcharge also cause scatter in the energy economy value as shown in table II.

\section{Rolling Resistance of Tires}

Towing tests were used to determine the rolling resistance of the tires as a function of temperature. The method used for these tests is described in reference 3. The results of the tests are given in figure 13. Corrections for power losses in the power-train wheel bearings and brakes have not been made and are expected to be about 0.002 kilogram per kilogram of vehic.le. we ight.

During the range tests tire temperature was recorded as a function of time. This relationship for vehicle speeds of 40,56 , and $69 \mathrm{kilnmeters} \mathrm{per} \mathrm{hour}$ $(25,35$, and $43 \mathrm{mph})$ is shown in fiqures $14(\mathrm{a}),(\mathrm{b})$, and (c) respectively. The undulations that are apparent in the temperature trace are due to the heat received by the tire from radiation from the Sun. The timing of the undulations corresponds to laps of the track. 
A11 the tests were conducted at the Transportation Research Center (TRC). of Ohio (fig. Al). This facility was built by the State of Ohio and is now operated by a contractor and supported by the State of 0hio. It is located 72 kilometers northwest of Columbus along U.S. route 33 near East Liberty, Ohio.

The test track is a 12-kilometer (7.5-mile) continuous loop 1.6 kilometers

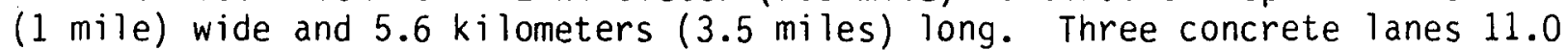
meters $(36 \mathrm{ft}$ ) wide in the straightaways and 12.8 meters $(42 \mathrm{ft}$ ) wide in the curves make up the high-speed test area. The lanes were designed for speeds of 129,177 , and $225 \mathrm{kilometers} \mathrm{per} \mathrm{hour}(80,110$, and $140 \mathrm{mph})$ with zero lateral acceleration in the curves. The 3.0-kilometer(1.88-mile-) long straightaways are connected to the constant 731 -meter(2400-ft-) radius curves by a short, variable-radius transition section. Adjacent to the inside concrete lane is a 3.66-meter(12-ft-) wide asphalt berm. This berm is only banked slightly to provide a drainage slope. An additional asphalt lane 3.66 meters $(12 \mathrm{ft})$ wide is located adjacent to the outside lane on the straightaways. The constant-speed and cycle tests were conducted on the inside asphalt lanes because all these tests were conducted at relatively low speeds. The acceleration and coast-down tests were conducted on the straight outside concrete lane. The track has a constant 0.228 -percent north-to-south downslope. The TRC complex also has a 20-hectare (50-acre) vehicle dynamics area, and a 2740-meter (9000-ft-) long skid pad for the braking and handling tests. 


\section{APPENDIX B}

\section{VEHICLE PREPARATION AND TEST PROCEDURE}

\section{Vehicle Preparation}

When the vehicle was received at the test track, a number of checks were made to assure it was ready for performance tests. The vehicle was examined for physical damage when it was removed from the transport vehicle. Before the vehicle was driven, a complete visual check was made of the entire vehicle including wiring, batteries, motor, and controller. The vehicle was weighed, and the wheel alignment was checked. The battery was changed, and the specific gravities were checked to determine if the batteries were equalized. The instrumentation was then installed.

\section{Test Procedure}

Data taken before driving and after each test were entered on the vehicle data sheet (fig. B1). These data included:

(1) Test weight of the vehicle

(2) Tire pressurc

(3) Tire contained air temperature

(4) Ambient temperature

(5) Wind speed and direction

(6) Track surface temperature

(7) Odometer reading

Prior to the test the specific gravity of each cell. of the battery was recorded.

To prepare for the test the instrumentation was turned on and warmed up. The vehicle was towed to the starting point on the track. At this point the $f$ ifth wheel distance counter and current integrator were reset to zero and checked off on the data sheet checklist. The test was then performed. After the vehicle was brought to a stop at the end of the test, pnst.esst data were taken and recorded. The driver recorded on the data sheet tire pressure and temperature, track surface temperature, time of run, odometer reading, fifth wheel distance, ambient temperature, wind conditions, and current-integrator reading. The fifth wheel was raised, and the vehicle was towed to the garage. The specific gravities for all cells of the battery were recorded.

\section{Weather Data}

Wind velocity, ambient temperature, and barometric pressure were measured at the beginning and end of each test. The wind anemometer was located about 1.8 meters $(6 \mathrm{ft})$ from ground level near the center of the east straightaway (fig. B1). The ambient air temperature and barometric pressure were measured in the control tower adjacent to the anemometer but at a higher elevation. During many test runs the winds were variable and gusty. The ground elevation at the anemometer was 3 meters higher than the track elevation, which meant the wind was measured above the path of the vehicles. Also, the large physical size and high banked curves of the track frequently resulted in local wind conditions that differed from the recorded values. 
Cycle Timer

The cycle timer was designed to assist the vehicle driver in accurately driving SAE schedules $b$ and $C$. The required test profile is permanently stored on a programmable read-only memory (PROM), which is the heart of the instrument. This profile is continuously reproduced on one needle of a dual-movement analog meter. The second needle is connected to the output of the fifth wheel, and the driver matches needles to accurately drive the required schedule.

One second before each speed transition (e.g., acceleration to cruise or cruise to coast) a signal sounds to forewarn the driver of a change. A longer duration signal sounds after the idle period to emphasize the start of a new cycle. The total number of test cycles driven is stored in a counter and can be displayed at any time with a pushbutton (to conserve power). 


\section{REFERENCES}

1. Schwab, John R.: Performance of a $14.9 \mathrm{~kW}$ Laminated-Frame dc Series Motor with Chopper Controller. DOE/NASA/1044-79/2, NASA TM-79177, 1979.

2. Sargent, Noel B.; et al.: Baseline Tests of the C. H. Waterman Daf Electric Passenger Vehicle. CONS/1011-2, NASA TM-73757, 1977.

3. Dustin, Miles 0.; and Slavik, Ralph J.: Rolling Resistance of Electric Vehicle Tires from Track Tests. NASA TM-82836, 1982. 
TABLE I. - MUTUR DATA

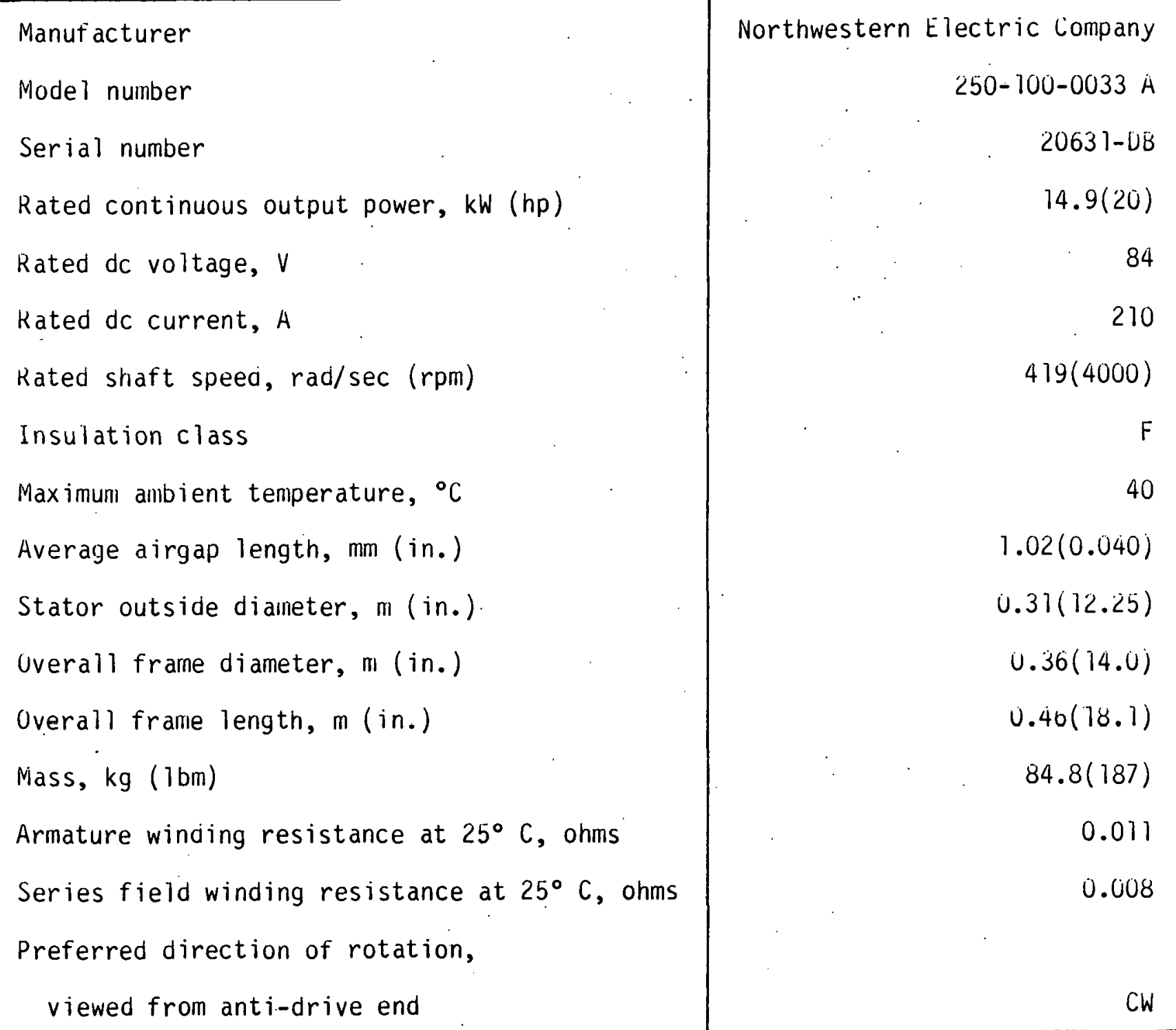


TABLE I1. - SUMMARY OF TEST RESULTJ

\begin{tabular}{|c|c|c|c|c|c|c|c|c|c|c|c|c|c|}
\hline \multirow[t]{2}{*}{ Test date } & \multicolumn{2}{|c|}{ Tes: sjeed (ccnstant) } & \multicolumn{3}{|c|}{ hird velocity } & \multicolumn{2}{|c|}{ Temperature } & \multicolumn{2}{|c|}{ Fiange } & \multicolumn{2}{|c|}{ Energy } & \multicolumn{2}{|c|}{ Energy consumption } \\
\hline & $\mathrm{kg} / \mathrm{hr}$ & $\mathrm{mph}$ & & $\mathrm{km} / \mathrm{hr}$ & $m p h$ & की & ${ }^{\circ} \mathrm{F}$ & $\mathrm{km}$ & mite & MJ & $\mathrm{kW}-\mathrm{hr}$ & $M J / \mathrm{km}$ & kW-hr/mite \\
\hline $\begin{array}{l}5-21-81 \\
5-29-81 \\
6-2-31 \\
6-4-81 \\
6-11-31 \\
6-12-31 \\
6-16-31 \\
6-18-31\end{array}$ & $\begin{array}{l}56 \\
40 \\
(a) \\
56 \\
69 \\
(b) \\
4 J \\
56\end{array}$ & $\begin{array}{l}35 \\
25 \\
(a) \\
35 \\
43 \\
(b) \\
25 \\
35\end{array}$ & is & $\begin{array}{l}\text { to } 8 \\
\text { to } 16 \\
\text { to } 16 \\
\text { to } 19 \\
\text { to } 8 \\
\text { to } 18 \\
\text { to } 23 \\
\text { to } 16\end{array}$ & 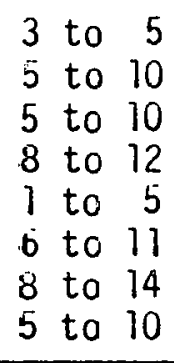 & $\begin{array}{l}23 \\
24 \\
22 \\
27 \\
20 \\
27 \\
27 \\
27\end{array}$ & $\begin{array}{l}73 \\
75 \\
71 \\
80 \\
68 \\
80 \\
80 \\
70\end{array}$ & $\begin{array}{c}84 \\
100 \\
3 \overline{1} \\
8 \bar{c} \\
58 \\
4 \bar{c} \\
98 \\
81\end{array}$ & $\begin{array}{l}52 \\
62 \\
23 \\
51 \\
36 \\
30 \\
61 \\
30\end{array}$ & $\begin{array}{r}72 \\
94 \\
90 \\
83 \\
58 \\
97 \\
104 \\
90\end{array}$ & $\begin{array}{l}20 \\
26 \\
25 \\
23 \\
16 \\
27 \\
24 \\
25\end{array}$ & $\begin{array}{l}0.85 \\
.94 \\
2.43 \\
1.01 \\
.98 \\
2.01 \\
1.05 \\
1.12\end{array}$ & $\begin{array}{r}0.38 \\
.42 \\
1.09 \\
.45 \\
.44 \\
.90 \\
.47 \\
.50\end{array}$ \\
\hline
\end{tabular}

aDriving cycle schedsle $C$.

boriving cycle schedıle $B$. 
TABLE III. - MAXIMUM ACCELERATION AND GRADABILITY

(a) Battery 10 percent discharged

\begin{tabular}{|c|c|c|c|c|c|}
\hline \multirow{2}{*}{$\begin{array}{c}\text { Time, } \\
\text { sec }\end{array}$} & \multicolumn{2}{|c|}{ Vehicle speed } & \multicolumn{2}{|c|}{ Vehicle acceleration } & \multirow{2}{*}{$\begin{array}{c}\text { Gradability, } \\
\text { percent }\end{array}$} \\
\cline { 2 - 5 } & $\mathrm{km} / \mathrm{hr}$ & $\mathrm{mph}$ & $(\mathrm{km} / \mathrm{hr}) / \mathrm{sec}$ & $\mathrm{mph} / \mathrm{sec}$ & \\
\hline & & & & & \\
0 & 0 & 0 & 6.88 & 4.28 & 19.8 \\
2 & 9.0 & 5.6 & 5.79 & 3.60 & 16.6 \\
4 & 20.9 & 13.0 & 4.83 & 3.00 & 13.8 \\
6 & 31.4 & 19.5 & 3.99 & 2.48 & 11.4 \\
8 & 38.6 & 24.0 & 3.27 & 2.03 & 9.3 \\
10 & 43.9 & 27.3 & 2.65 & 1.65 & 7.5 \\
12 & 48.1 & 29.9 & 2.12 & 1.32 & 6.0 \\
14 & 51.5 & 32.0 & 1.69 & 1.05 & 4.8 \\
16 & 54.2 & 33.7 & 1.35 & .84 & 3.8 \\
18 & 56.6 & 35.2 & 1.08 & .67 & 3.0 \\
20 & 58.9 & 36.6 & .88 & .55 & 2.5 \\
22 & 60.5 & 37.6 & .71 & .44 & 2.0 \\
24 & 62.1 & 38.6 & .61 & .38 & 1.7 \\
26 & 63.4 & 39.4 & .56 & .35 & 1.6 \\
28 & 64.7 & 40.2 & .51 & .32 & 1.5 \\
30 & 65.6 & 40.8 & .50 & .31 & 1.4 \\
\hline
\end{tabular}

(b) Battery 80 percent discharged

\begin{tabular}{|c|c|c|c|c|c|}
\hline \multirow{2}{*}{$\begin{array}{c}\text { Time, } \\
\text { sec }\end{array}$} & \multicolumn{2}{|c|}{ Vehicle speed } & \multicolumn{2}{c|}{ Vehicle acceleration } & \multirow{2}{*}{$\begin{array}{c}\text { Gradability, } \\
\text { percent }\end{array}$} \\
\cline { 2 - 5 } & $\mathrm{km} / \mathrm{hr}$ & $\mathrm{mph}$ & $(\mathrm{km} / \mathrm{hr}) / \mathrm{sec}$ & $\mathrm{mph} / \mathrm{sec}$ & 12.8 \\
\hline 0 & 0 & 0 & 4.5 & 2.80 & 11.5 \\
2 & 7.7 & 4.8 & 4.04 & 2.51 & 10.3 \\
4 & 15.0 & 9.3 & 3.62 & 2.25 & 9.1 \\
6 & 21.7 & 13.5 & 3.22 & 2.00 & 8.1 \\
8 & 28.8 & 17.9 & 2.85 & 1.77 & 7.1 \\
10 & 34.8 & 21.6 & 2.49 & 1.55 & 6.2 \\
12 & 39.7 & 24.7 & 2.17 & 1.35 & 5.3 \\
14 & 43.4 & 27.0 & 1.88 & 1.17 & 4.5 \\
16 & 46.7 & 29.0 & 1.59 & .99 & 3.8 \\
18 & 49.2 & 30.6 & 1.35 & .84 & 3.2 \\
20 & 51.3 & 31.9 & 1.13 & .70 & 2.6 \\
22 & 53.3 & 33.1 & .93 & .58 & 2.2 \\
24 & 54.9 & 34.1 & .77 & .48 & 1.8 \\
26 & 56.3 & 35.0 & .63 & .39 & 1.5 \\
28 & 57.6 & 35.8 & .51 & .31 & 1.2 \\
30 & 58.6 & 36.4 & .43 & .27 & \\
\hline
\end{tabular}


TABLE IV. - RUAD PUWEK ANO ENERGY

\begin{tabular}{|c|c|c|c|c|c|c|}
\hline \multirow{2}{*}{$\begin{array}{c}\text { Time, } \\
\text { sec }\end{array}$} & \multicolumn{2}{|c|}{ Vehicle speed } & \multicolumn{2}{c|}{ Road power } & \multicolumn{2}{c|}{ Koad energy } \\
\cline { 2 - 7 } & $\mathrm{km} / \mathrm{hr}$ & $\mathrm{mph}$ & $\mathrm{kW}$ & $\mathrm{hp}$ & $\mathrm{kW}-\mathrm{hr} / \mathrm{km}$ & $\mathrm{kW}-\mathrm{hr} / \mathrm{mile}$ \\
\hline 5 & 74.9 & 46.5 & 6.86 & 9.20 & 0.091 & 0.147 \\
10 & 71.0 & 44.1 & 6.22 & 8.34 & .088 & .141 \\
20 & 63.7 & 39.6 & 5.13 & 6.88 & .081 & .130 \\
30 & 57.1 & 35.5 & 4.25 & 5.69 & .075 & .120 \\
40 & 50.8 & 31.6 & 3.52 & 4.72 & .069 & .111 \\
50 & 45.1 & 28.0 & 2.92 & 3.92 & .065 & .104 \\
60 & 39.6 & 24.6 & 2.42 & 3.25 & .061 & .098 \\
70 & 34.5 & 21.4 & 2.00 & 2.68 & .058 & .093 \\
80 & 29.6 & 18.4 & 1.63 & 2.19 & .055 & .088 \\
90 & 25.0 & 15.5 & 1.31 & 1.76 & .052 & .084 \\
100 & 20.6 & 12.8 & 1.03 & 1.38 & .050 & .081 \\
110 & 16.3 & 10.1 & .78 & 1.04 & .048 & .077 \\
120 & 12.3 & 7.7 & .56 & .75 & .045 & .073 \\
130 & 8.5 & 5.3 & .36 & .48 & .042 & .068 \\
140 & 5.0 & 3.1 & .20 & .26 & .040 & .064 \\
150 & 1.8 & 1.1 & .06 & .08 & .034 & .054 \\
\hline
\end{tabular}




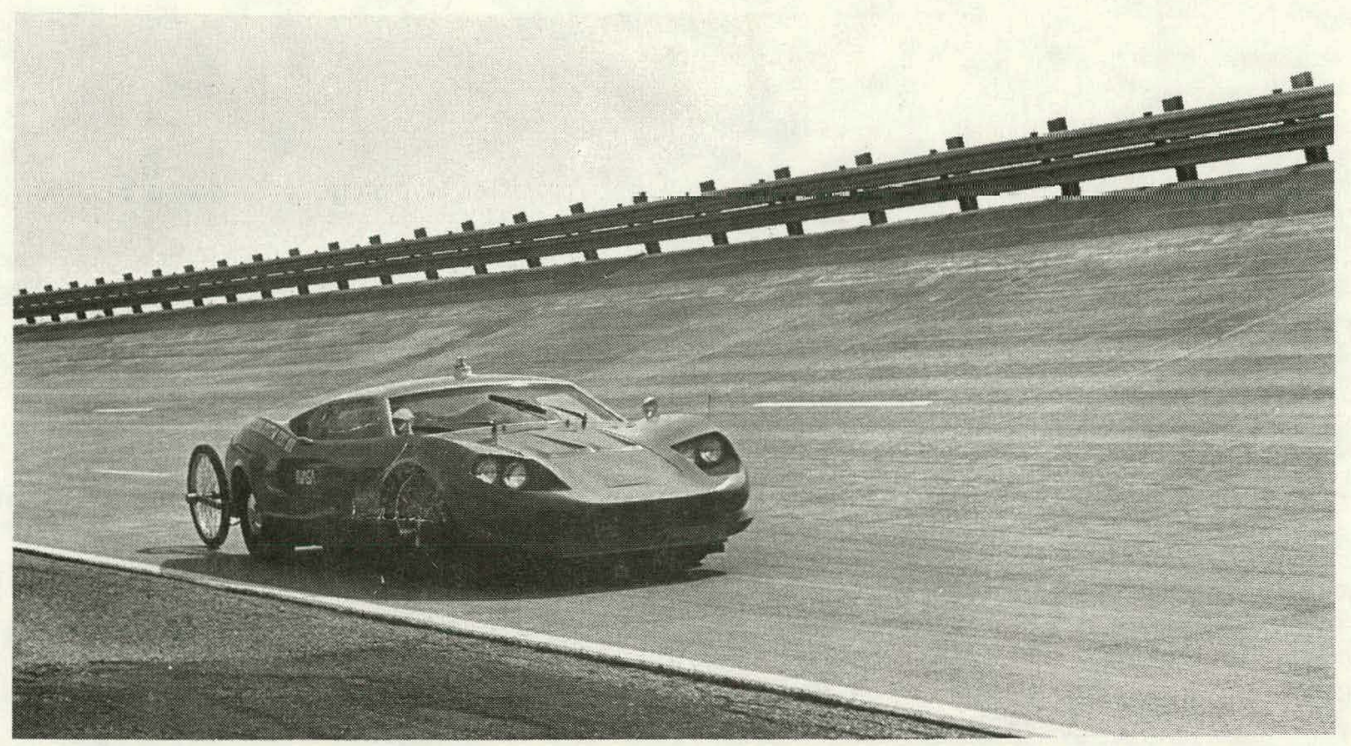

Figure 1. - Electric propulsion system test vehicle.

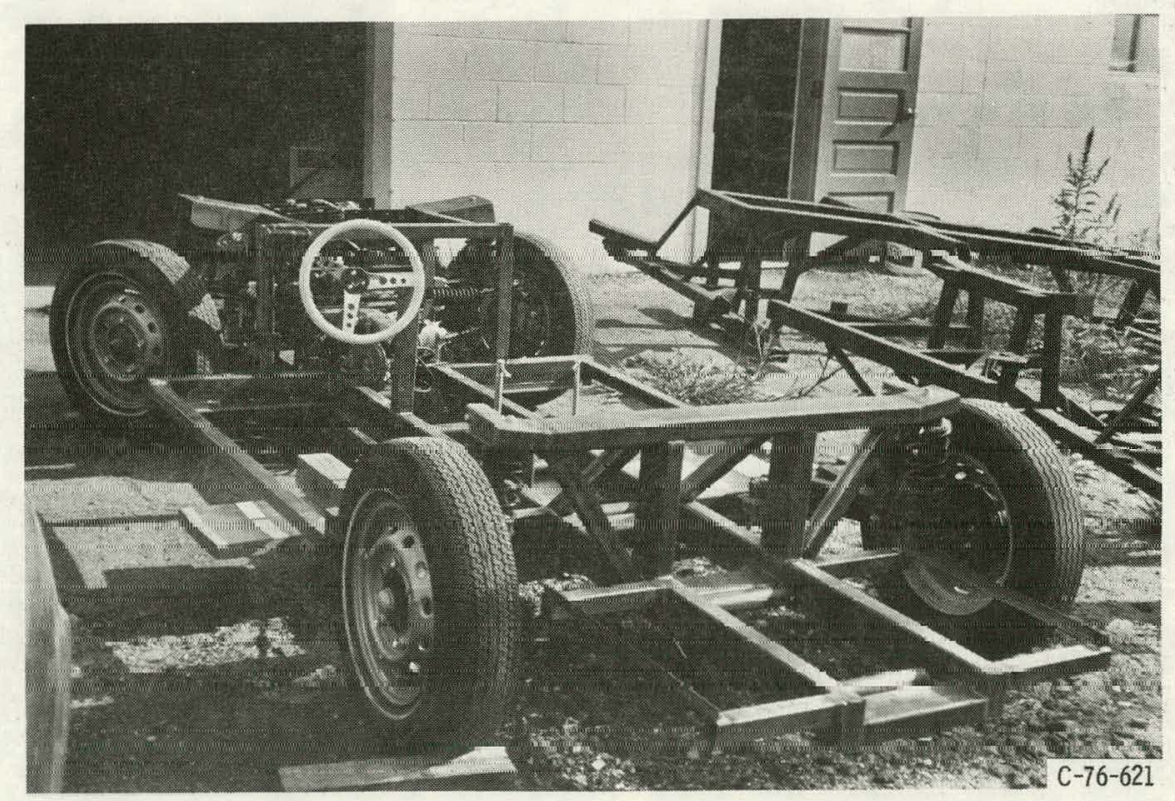

Figure 2. - Vehicle without body showing frame and battery tunnel construction. 

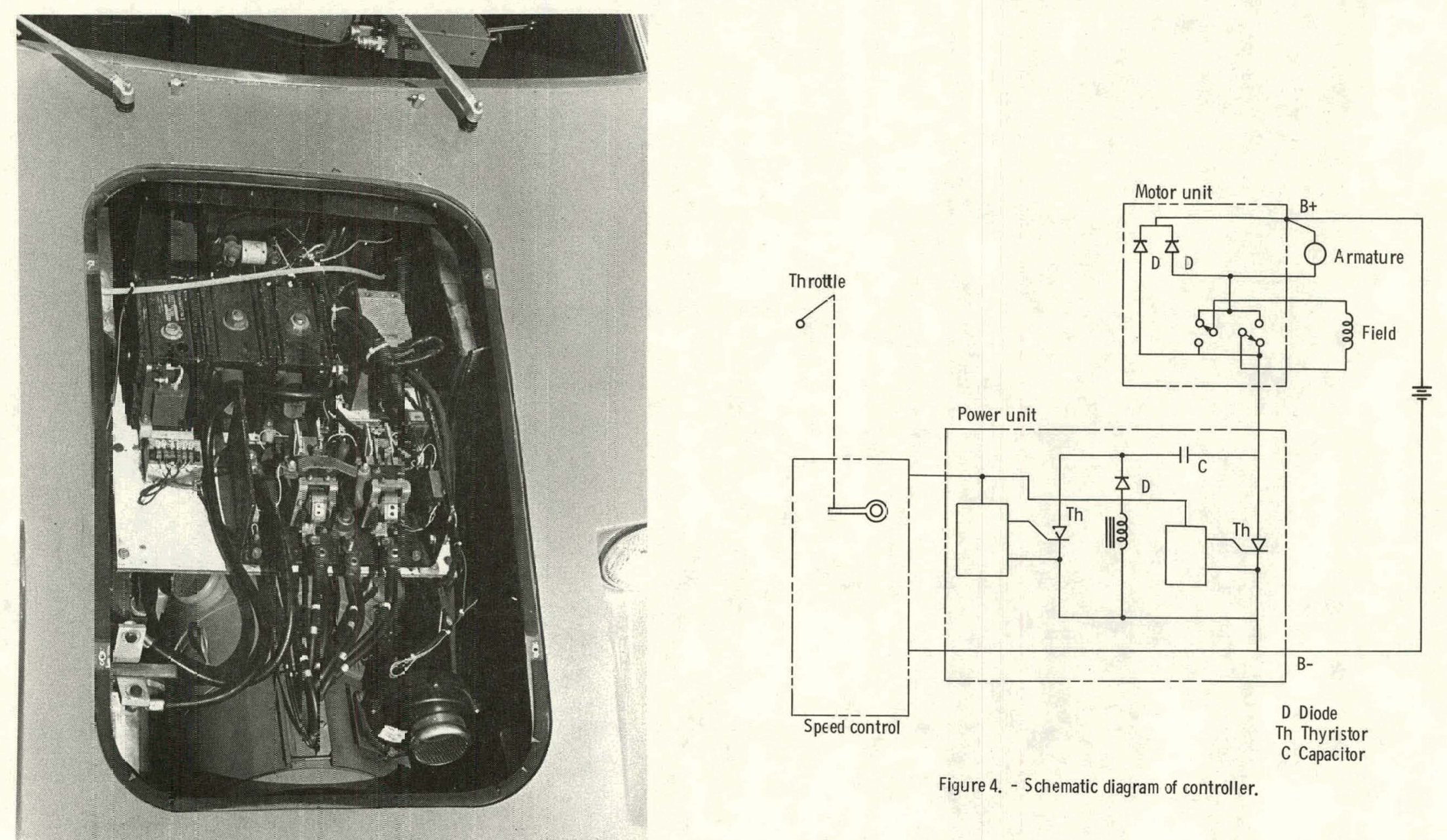

Figure 3. - Traction motor and controller.

Figure 4. - Schematic diagram of controller. 


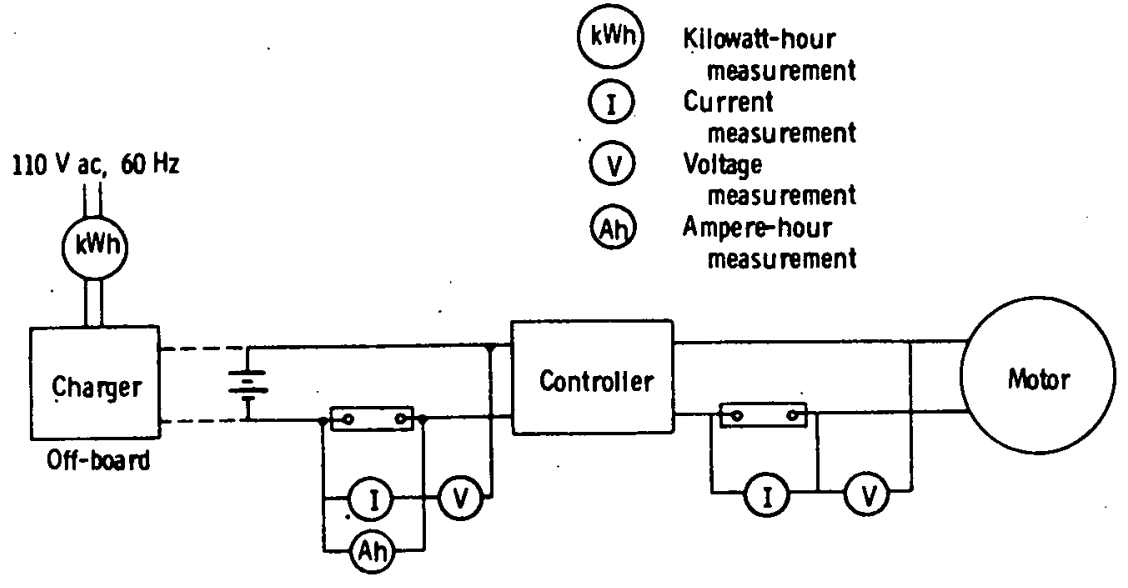

Flgure 5. - Instrumentation schematic.

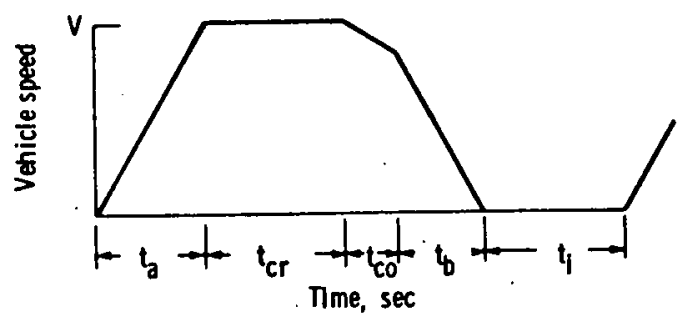

\begin{tabular}{|l|r|r|r|}
\hline \multirow{2}{*}{ Test parameter } & \multicolumn{3}{|c|}{ SAE } \\
& \multicolumn{2}{|c|}{ Schedules } \\
\cline { 2 - 4 } & $B$ & $C$ & $D$ \\
\hline Maximum speed, V, mph & 20 & 30 & 45 \\
Acceleration time, ta, sec & 19 & 18 & 28 \\
Cruise time, tcr & 19 & 20 & 50 \\
Coast time, tco & 4 & 8 & 10 \\
Brake time, to & 5 & 9 & 9 \\
ldle time, t & 25 & 25 & 25 \\
\hline
\end{tabular}

Flgure 6. - SAE J2Z7a driving cycle schedules. 


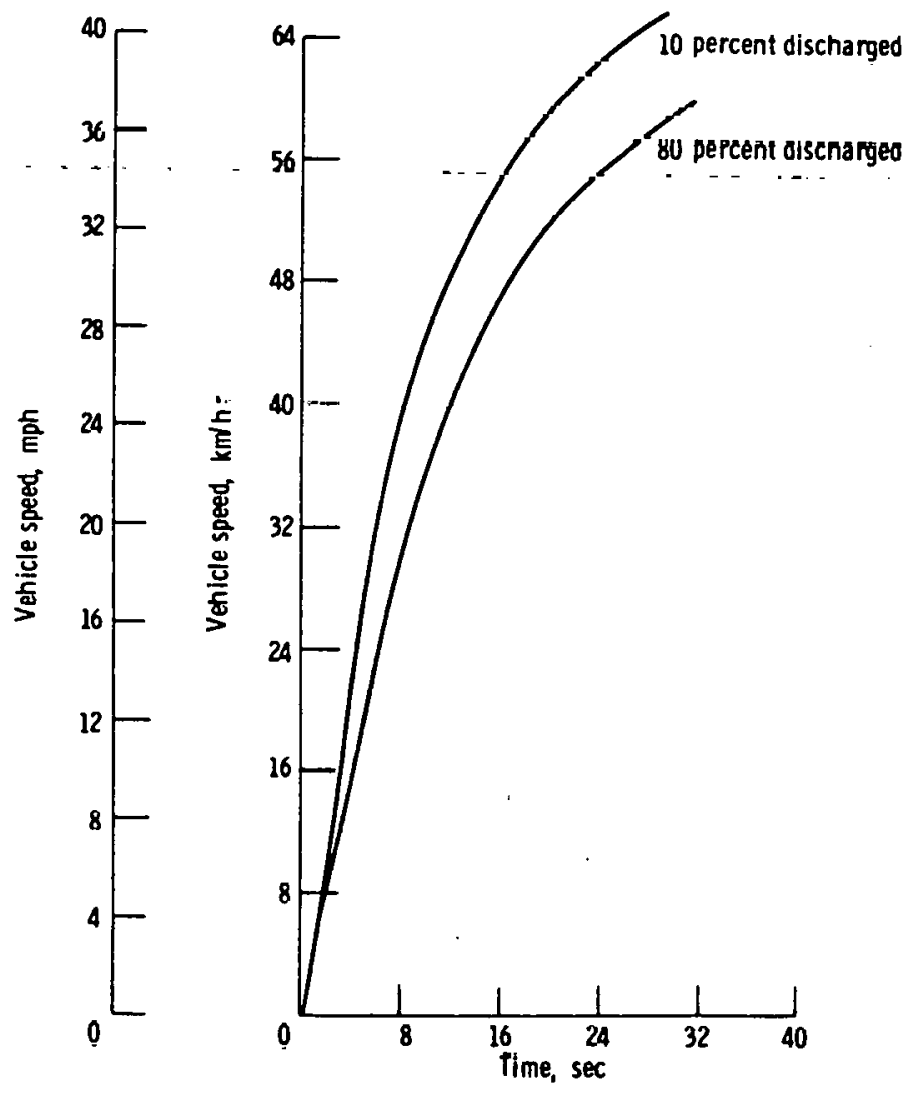

Figure 7. - Vehicle speed as function of time during maximum acceleration. 


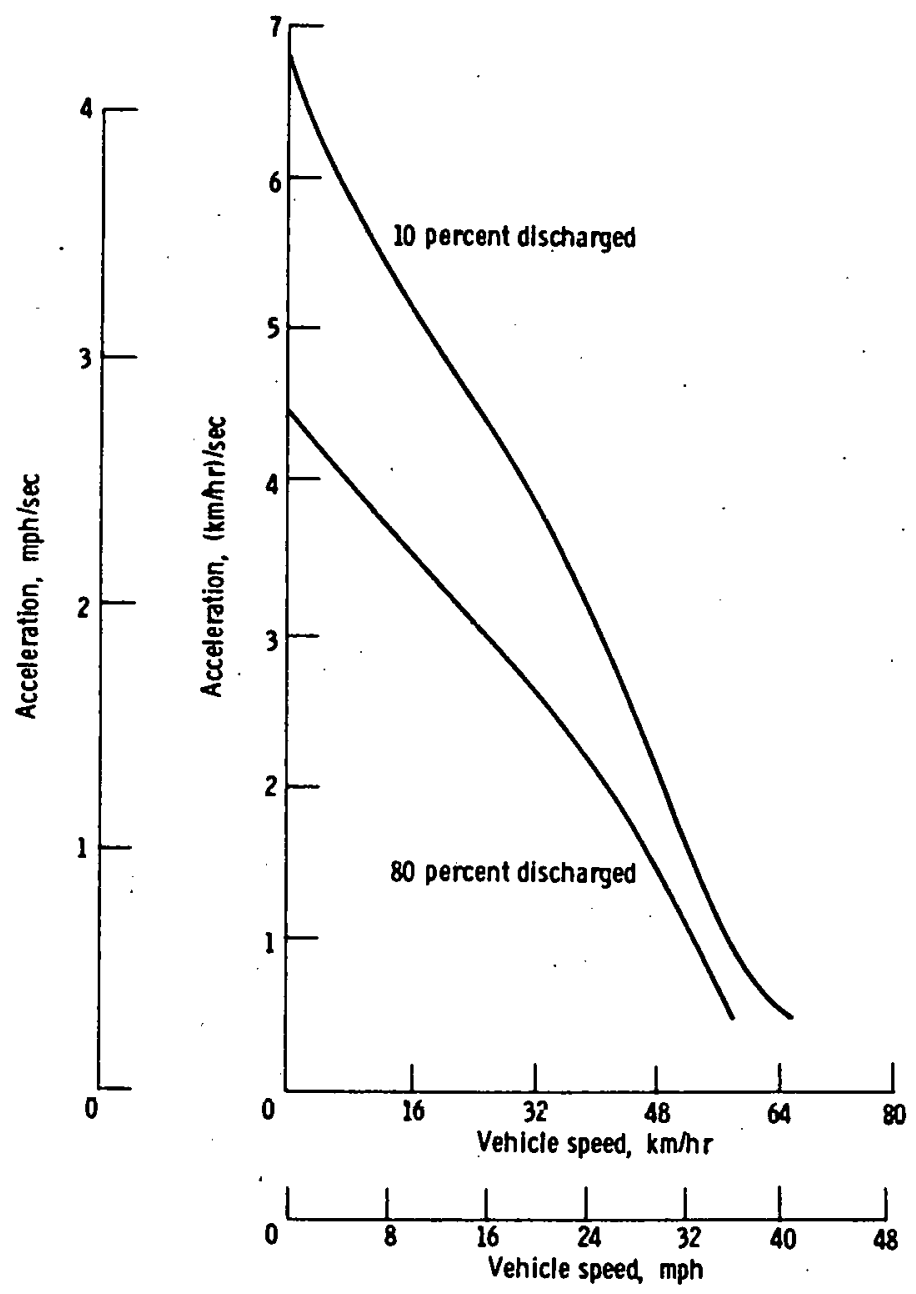

Figure 8. - Maximum acceleration as function of vehicie speed. 


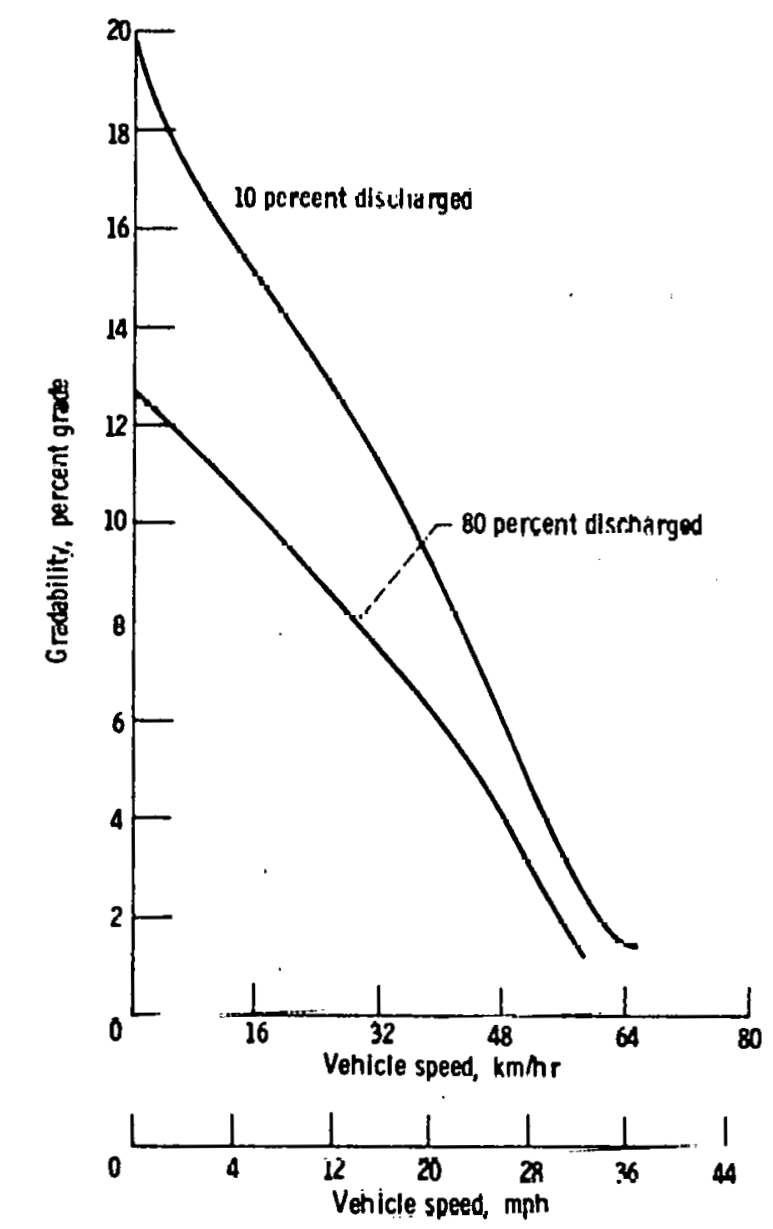

Figure 9. - Gradablitity as function of vehicle speed. 


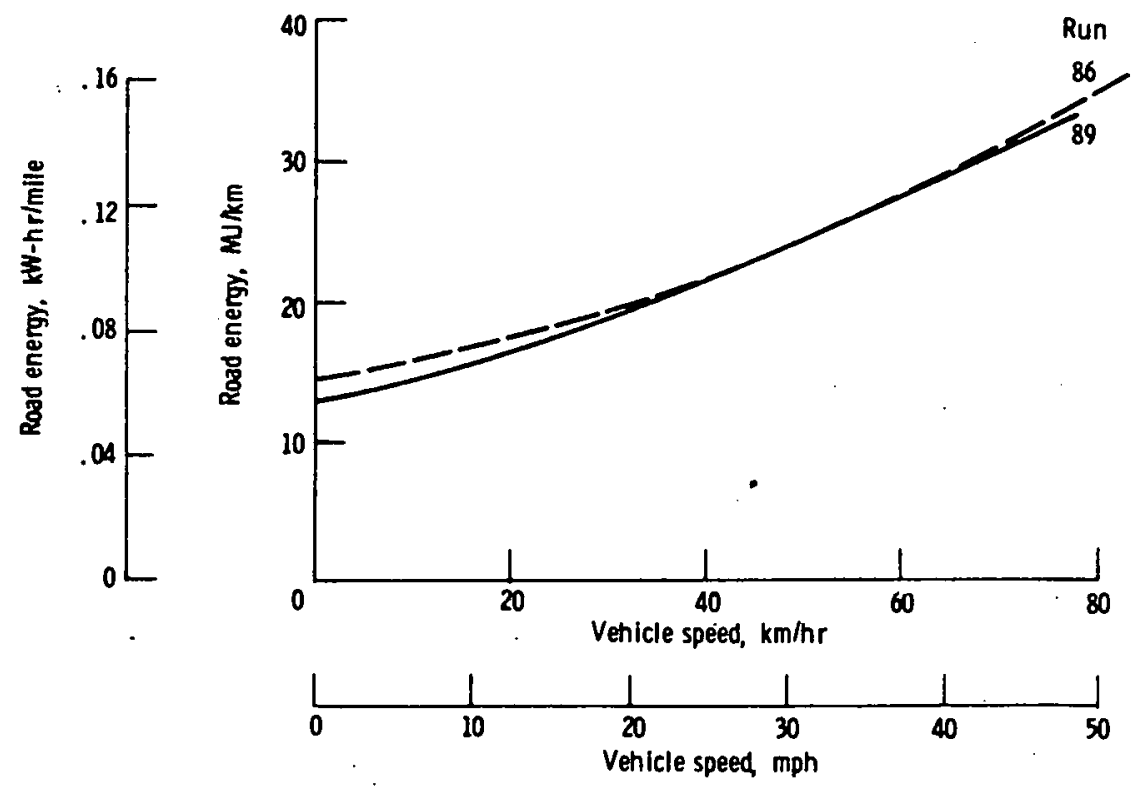

Figure 10. - Road energy as function of vehicle speed.

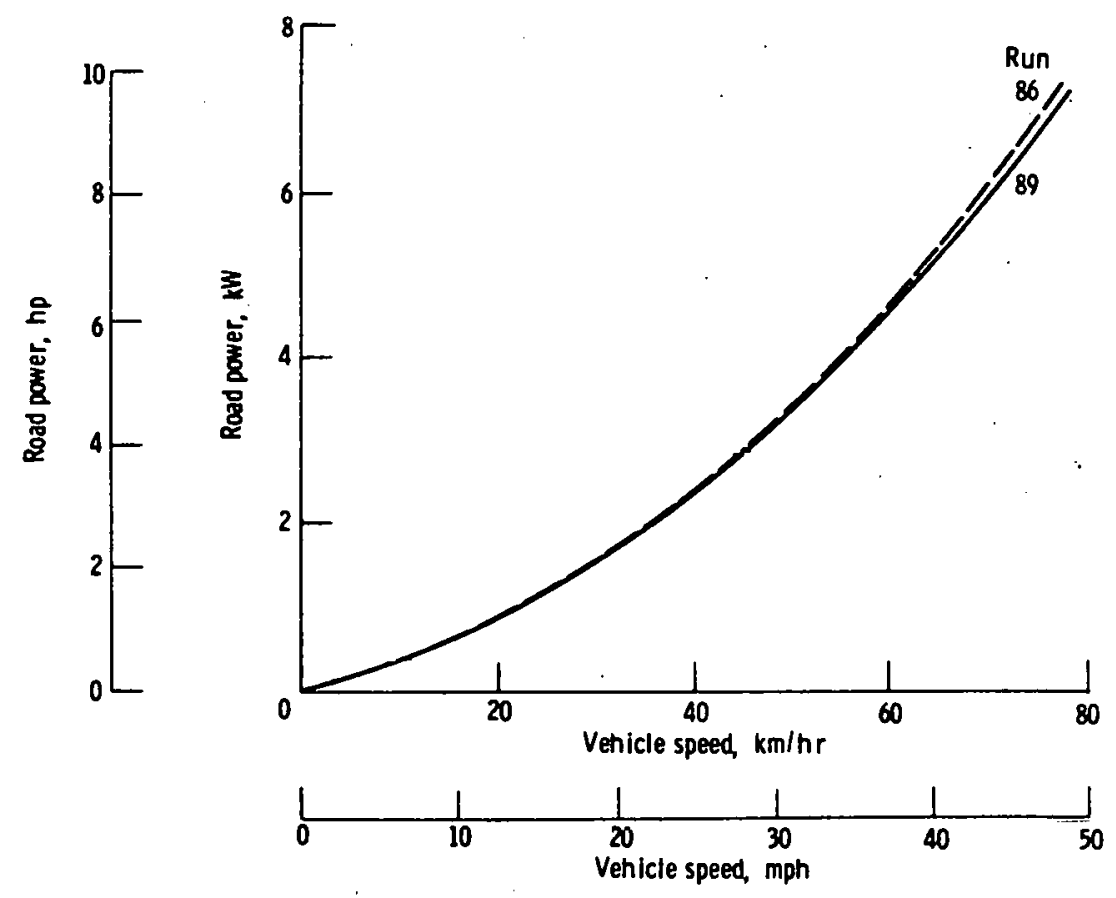

Figure 11. - Road power as function of vehicle speed. 


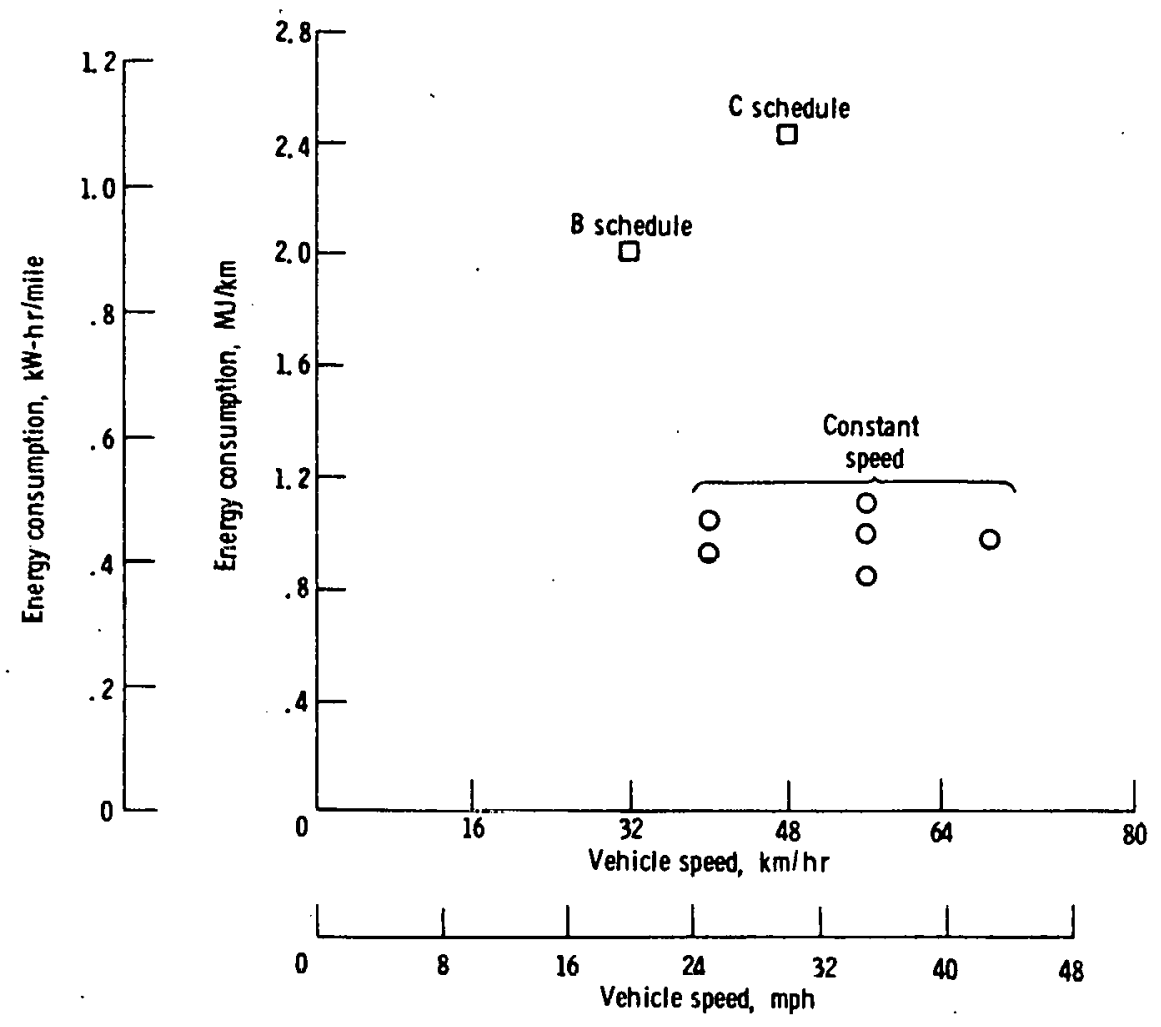

Figure 12 - Energy economy as function of vehicle speed.

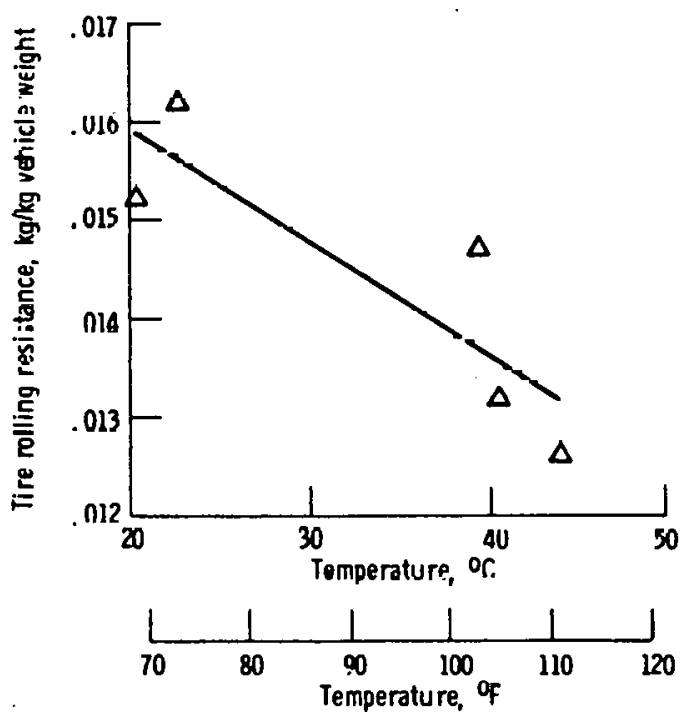

Figure 13. - Tire rolling resistance as function of tire containcd air temperature. 

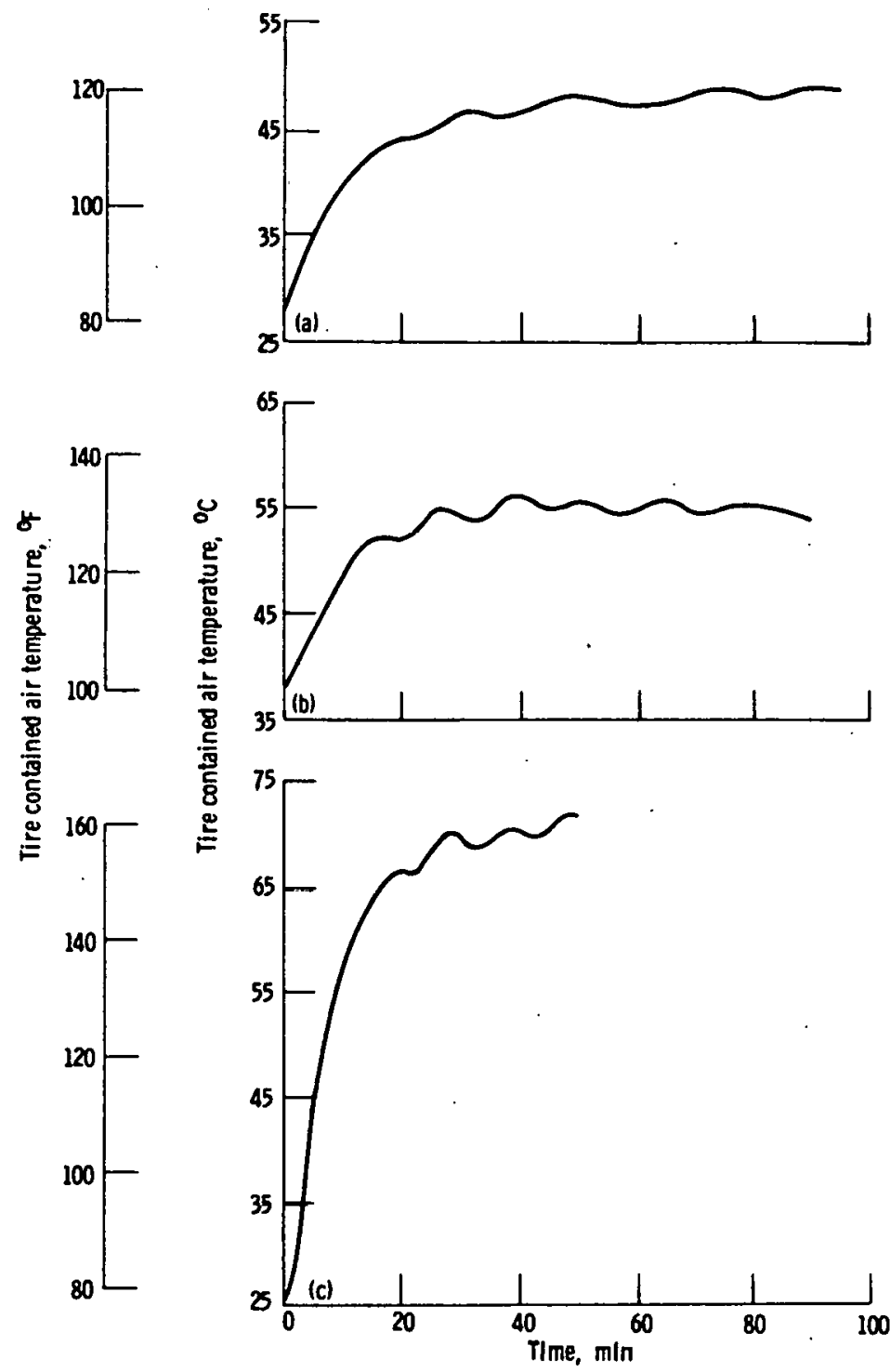

(a) Speed, 40 kilometers per hour (25 mph).

(b) Speed, 56 kilometers per hour $(35 \mathrm{mph})$.

(c) Speed, 69 kilometers per hour (43 mph).

Figure 14. - TIre contained alr temperature as function of tIme. 


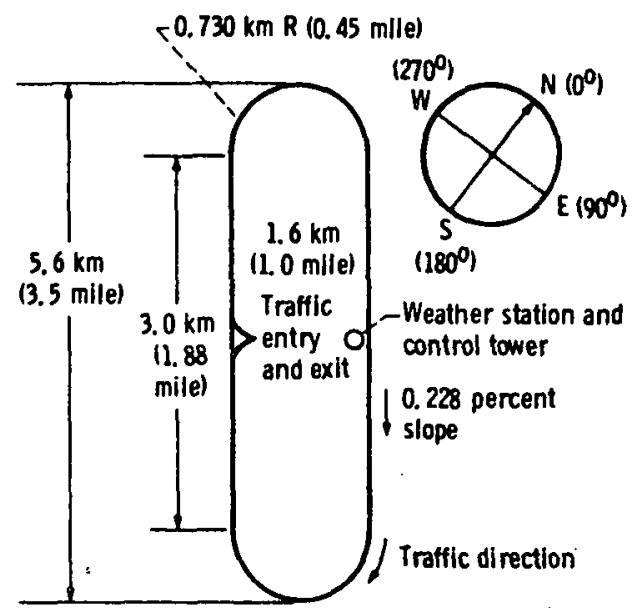

Flgure Al. - Characteristics of Transportation kesearch Ceniler Tesl Track. kast Liberty, Ohia.

TEST DATA SHEET

ELECTRIC VEHICLE TESTS

Test Run No.

Test Description

Date

Vehicle

Driver Time of day

PRETEST DATA

Weight: front Tirc Pressure Amblent Temp. Track Temp. Track Mile Marker Check Off:

$$
\begin{aligned}
& \text { Inverter.. } \\
& \text { timer } \\
& \text { cycle timer }
\end{aligned}
$$

$+2$

To

\section{POSTIEST DATA:}

TIre Pressure

Time of Run

Distance Readout

Amblent Temp.

Raise 5th Wheel

Total

Rear

Tife Iémperature

Wind. $\mathrm{MPH}$ at

Odometer ....

Strip Chant Speed

strip sharts distance counter integrator

Sth wheal -

Comments:

Figure D1. - Vehicle test data shect.
Track Temperature Milc Morker

Odometer

No. of Laps No. of Cycles MPH at Integrator Reading ___ $\mathrm{kW}-\mathrm{hr}$ 


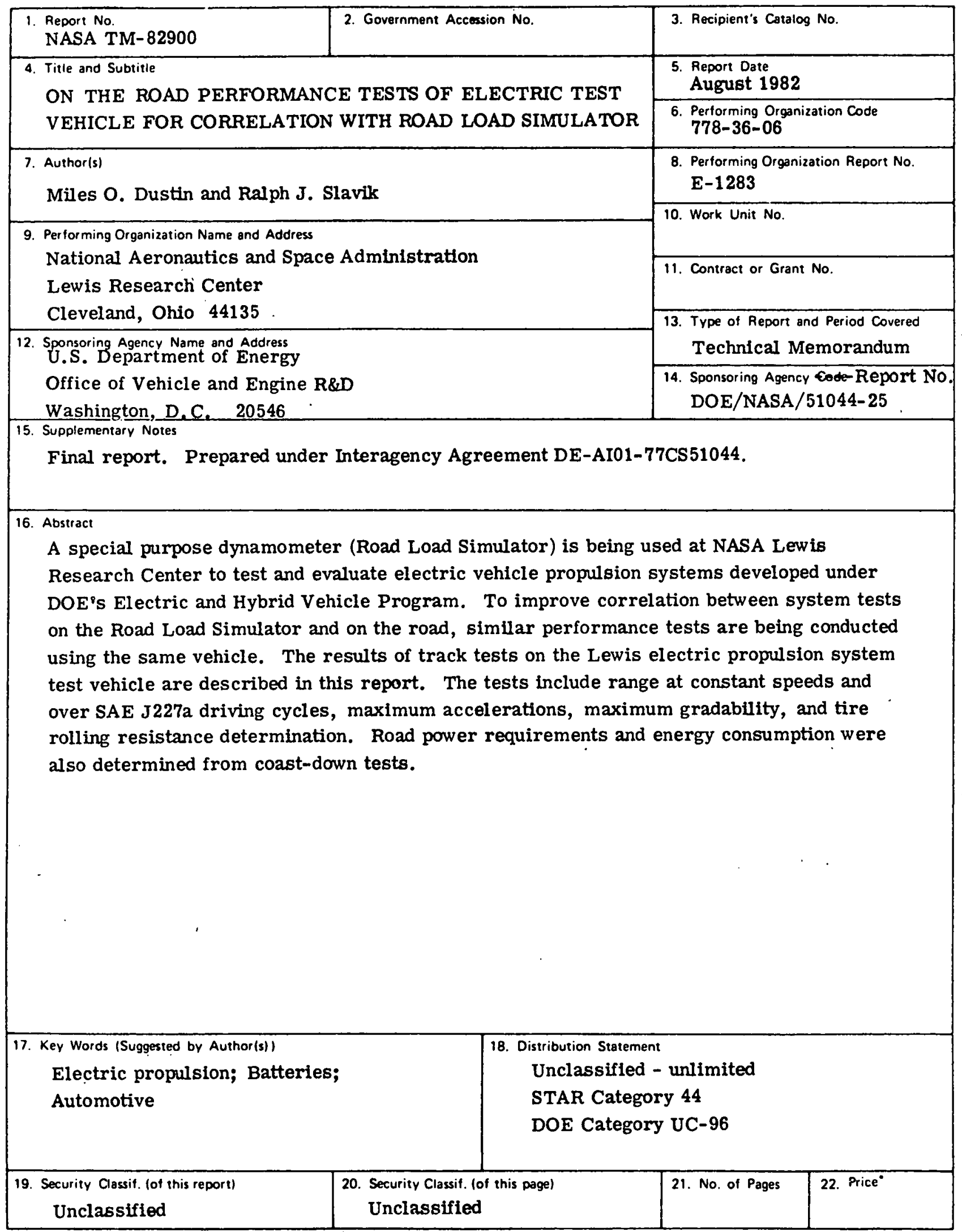

- For sale by the National Technical Information Service, Springfield, Virginia 22161 